\title{
A Guide to Theological Reflection: A Fresh Approach for Practical Ministry Courses and Theological Field Education
}

\author{
Wilson, Jim L. and Earl Waggoner. 2020. A Guide to Theological Reflection: A Fresh Ap- \\ proach for Practical Ministry Courses and Theological Field Education. Grand Rapids, \\ MI: Zondervan Academic. 192pp. \$3.99 Paperback. ISBN: 978-0-310-09393-0.
}

Fides quaerens intellectum. (Faith seeking understanding.) —Saint Anselm (1033-1109)

Jim Wilson and Earl Waggoner's new book, A Guide to Theological Reflection, reviews other models of theological reflection and introduces their model, which they describe as a "fresh approach ... grounded in the specific practice of ministry" (16). The book functions as a practical guide. It is divided into two sections: three chapters on the theological reflection process and six chapters on the tools of theological reflection. Each chapter begins with a mini-summary called "At a Glance"-a box highlighting the key points. The key points and terminology are further defined with references to Christian scriptures. Wilson and Waggoner have included helpful graphics to illustrate the theological reflection models. They provide examples from real life, created with the help of a research team of faculty and students, that illustrate the concepts and tools (artifacts, reflections, etc.). At the end, a six-page bibliography lists works by a diverse group of theologians and business gurus who are quoted throughout, contributing wise thoughts about the power of reflection. There is both a scripture and a general index.

As complex as faith is, so too is ministry. To be effective, one must navigate the spaces between faith, theology, personal and corporate experiences, and cultural realities. Theological reflection is a process whereby ministers examine their work and evaluate their leadership through the lens of their beliefs. Over the past forty years in institutions accredited by the Association of Theological Schools (ATS), theological reflection has focused on a process that incorporates biblical, historical, doctrinal and practical (or pastoral) data to help students reflect on challenges in ministry. Theological reflection, as defined by ATS, describes the practice of creating "an explicit connection between the information being provided in the classroom and the practice of ministry in the field" (17). In this time, a number of models have emerged for theological reflection.

Wilson and Waggoner are seminary faculty members at Gateway (Southern Baptist Convention) and Colorado Christian University (evangelical) respectively. They believe that theological reflection is integral to a faithful and obedient practice of ministry. It is not enough to have earned a degree and been ordained; a minister must be obedient and faithful in his relationship with God and the work he does on behalf of God. To this end, Wilson and Waggoner are advocates of regular, disciplined practices, personal prayer, and sessions where feedback is received. Together, these will help ministers become aware of what they don't know and what to work on. With these aids, ministers can grow personally, spiritually, and professionally while doing their work with wisdom, honesty, courage, and integrity (22).

This begins with "identifying how our beliefs, thoughts, and feelings influence our actions, aligning them to our best understanding of God's truth, and exploring possibilities for future ministry 
responses" (23). This understanding of theological reflection includes a pause-a time to reflect on the past and prepare for the future-what they call the reflection loop. This pause is the key to effective ministry, identifying not only what we believe but how we will respond. After searching for the truths in a situation, ministry is most effective when you can choose better actions.

Wilson and Waggoner recommend building a ministry support system-either a mentor or a team that will provide feedback. They emphasize the value of guidance from experienced, trustworthy people who will listen to you, challenge you, pray with you, and encourage you as you develop (63). They also acknowledge the value of connecting with a peer group as you begin your ministry.

The last step in their model is to explore options for ministerial response. This is aided by regular practices that create ministry artifacts (journals, case studies, verbatim reports). These will be familiar to those who have gone through clinical pastoral education, and they can be used either in one-on-one conversations or with a group of peers to clarify feelings. Wilson and Waggoner provide examples with details and explanations for each type of artifact. They also identify questions that may be helpful when used with an artifact during mentoring sessions.

In chapter 5, Wilson and Waggoner recommend using journals to track and analyze activities and how one spends time. This helps ministers to live and act with intention. If you say that you value time with family but you are not spending time with family, your journal record can help you to realign your time to fit with the values you profess. Ministry is a relational vocation, knowing how you spend your time helps you to invest in your relationships.

The last chapter looks at metrics for success in ministry. For some, success may be measured in numbers (number of weekly worshippers, your church building, how much you make, how fast your church is growing), but Wilson and Waggoner end with a reminder that we are called to obey, to use our ears to hear, and to use our lives to be humble, merciful, and to act with loving kindness (159). Christian faith is a covenantal and relational experience where obedience frees us and grounds us in a blessed, grace-filled life.

Though the writing style is simple and clear, students and ministers who are not evangelical Christians will find parts of the book challenging. The Christian perspective, the scripture quotes, and the terminology may obscure the message. The chapter on developing a growth covenant could be especially difficult. Even so, I found the process and the recommendations to be helpful for anyone wishing to identify areas where their daily practices do not follow their professed theology. Through setting goals and spending time in prayer, ministers can identify what they want to achieve. Some of the specific examples are achieving better health (lowering BMI and exercising) during a 12-month period, increasing personal prayer life, improving preaching skills, communication styles, and developing youth ministry skills. Again, as theological reflection requires action, so too does a process of creating a plan or covenant for change.

This guide to theological reflection will not be the last book to be written on the topic. Though written from an evangelical point of view, using language that may not be familiar, a sound process is offered. Ministers of any faith or denomination could adapt the concepts and practices to work with their faith and beliefs. All leaders have strengths and weaknesses. Part of the professional journey for anyone is to recognize that there will be areas where you are not an expert. To learn and improve means to listen, to look for answers that are meaningful, not superficial, and to recognize and accept the insights offered by others. Perhaps a different approach-one you have never tried-will make all the difference. The key to Wilson and Waggoner's approach is the disciplined approach to creating artifacts for reflection, the pause, and the feedback loop. Their model fosters a process that is tested and proven for theology and action to work together for transformation.

This book should be considered for all libraries where ministers are being educated or trained, whether or not theological reflection is a part of the curricula. Wilson and Waggoner's theological 
reflection model encourages healthy habits that will equip and prepare ministers for success while staying true to their beliefs. This is priceless.

Jennifer Bartholomew

Director of Library and Academic Support Services Sacred Heart Seminary and School of Theology

Franklin, WI 